\title{
The Bologna Process of German's Media and Communication Studies
}

\author{
Yoseph Bambang Wiratmojo ${ }^{1}$ \\ Department of Communication Science Universitas Atma Jaya Yogyakarta
}

\begin{abstract}
Internationalization of the higher education system through the Bologna Process in German's media and communication studies is on progress; all higher education institutions were chosen as the samples in this research had the same opinion that international student's mobility in term of the Bologna Process was the most important variable to create international cooperation with other universities. Providing more courses in English also became their main concern to attract international students come their academic life. The implementation of the new curricula model, bachelor and masters, was considered more transparent and clearer in the structure and content than the Diplom and Magister models. Nevertheless, the compatible and comparable qualification principle of bachelor and masters structure brought also dilemma that some of the content of media and communication studies had to be adjusted considering the workload and study period that is different from the old curricula systems. The bachelor and masters structure caused apprehension that the bachelor graduates would prefer to work in industries than return to campus to pursue higher degree.

This research was based on content analysis of curricula documents and interview transcription of some representative of HEl in media and communication studies.
\end{abstract}

Keywords: internationalization, the Bologna Process, curricula, media and communication studies

\begin{abstract}
Abstrak
Internasionalisasi sistem pendidikan tinggi melalui Proses Bologna pada kajian media dan komunikasi terus berlangsung di Jerman. Semua lembaga pendidikan tinggi yang dipilih sebagai sampel dalam penelitian ini memiliki pendapat yang sama bahwa mobilitas mahasiswa internasional adalah variabel yang paling penting untuk menciptakan kerjasama internasional dengan universitas lain. Menawarkan lebih banyak mata kuliah dalam bahasa Inggris juga menjadi perhatian utama mereka untuk menarik mahasiswa internasional masuk ke dalam kehidupan akademis mereka. Penerapan model kurikulum baru, sarjana S1 dan master (sarjana S2), dianggap lebih transparan dan jelas dalam struktur dan isi daripada Diplom dan Magister. Namun demikian, prinsip kompatibel dan sederajat pada kualifikasi sarjana S1 dan master (sarjana S2) membawa juga dilema bahwa kurikulum kajian media dan komunikasi harus disesuaikan dengan mempertimbangkan beban kerja dan masa studi yang berbeda dari sistem kurikulum lama. Terdapat juga kekhawatiran bahwa lulusan sarjana S1 akan lebih memilih untuk bekerja di industri daripada kembali ke kampus untuk mengejar gelar yang lebih tinggi. Penelitian ini didasarkan pada analisis isi dokumen kurikulum dan transkrip wawancara informan di beberapa lembaga pendidikan tinggi di bidang kajian media dan komunikasi di Jerman.
\end{abstract}

Kata kunci: internasionalisasi, Proses Bologna, kurikulum, kajian komunikasi dan media

${ }^{1}$ This paper was presented on the Indonesia International Conference on Communication, Jakarta $12^{\text {th }}$ of October 2010 
The Bologna Declaration, which promotes a European Higher Education Area (EHEA) based on an international cooperation and academic exchange, has become a milestone of the higher education system reformation in Europe. This declaration was signed by 29 countries in Bologna - Italy in 1999, and it was accomplished by 2010. The implementation of this declaration was furthermore being referred to as the "Bologna Process". It integrates some orientations, first orientation is providing academic degree standardization in a three-cycle structure: Bachelor, Masters, and Doctor. The second orientation is quality assurance standardization of higher education by developing comparable criteria and methodology. The third is a fair recognition of foreign degrees and other higher education qualifications in accordance with the Council of Europe/UNESCO Recognition Convention. The goals of these standardizations are that there would be open, free, and fair scientific cooperation among scientists in Europe.

Furthermore, the European Higher Education Area also facilitates the mobility of students, graduates, and higher education staff in order to build cooperation and academic exchange; to prepare students for their future careers, for their life as active citizens in democratic societies, and to support their personal developments; to offer broad access to high-quality higher education, based on democratic principles and academic freedom (Bologna Secretariat, 2007).

As one of the initiators of Bologna Declaration, Germany has a big role to support the Bologna Process successfully; because one main task of Germany was to become a pioneer to introduce the bachelor's and masters' curriculum system. Due to the Bologna Process, by 2010 the classic German qualification, Diplom and Magister, were disappear from all German university programs, and all universities in Germany offer only bachelor, masters, and doctoral programs. The Diplom degree was first introduced in universities of technology (Technische Hochschule) in 1899. This degree was granted to students who completed nine semesters of study, usually in technology or natural sciences, in a German university or university of applied sciences (Fachhochschule) whereas the Magister (complete name, Magister Artium) degree was introduced for the first time in 1957, and was granted to students who completed nine semesters of study in Humanities and Medicine (Knoke, 2007).

The implementation of the bachelor and masters qualifications makes the German higher education system more internationally recognized and more comparable to the common higher education qualifications used long before in other countries. The Bologna Process, which took time from 1999 until 2010, gave chance for Higher Education Institutions (HEI) to change gradually their old curricula systems, which were based on each previous state regulation, into one common European curriculum system. Some institutes or departments of media and communication studies had started earlier by launching their bachelor and masters programs; for example, the Department of Communication Science - University of Erfurt implemented its bachelor program in 1999 and masters program in 2002; the Institute of Journalism and Communication Research 
at the Hochschule für Musik und Theater (HMT) Hannover launched its bachelor program in 2001 and masters program in 2002; the Institute of Social Sciences, University of Düsseldorf, introduced its bachelor program in 2002 and masters program 2002 (Rössler, 2002, p. 22-23).

The internationalization of the higher education system in Germany influenced more or less one crucial aspect, the curriculum. Before the Bologna Process began, Germany had a very specific curriculum in its higher education system. The first degrees were called Diplom and Magister Artium, and the second degree was Doctor (Dr. phil.). The study period for the Diplom degree was equal to that of the bachelor plus masters degrees, but structurally they were different. The Diplom structure consisted of two study periods: the initial study stage (Vordiplom) usually took 2 years; and the main one (Hauptstudium) usually took 3 years; and it completed with one, and sometimes more, research projects (Studienarbeit), and a Diplom Thesis (Diplomarbeit) at the end of the study. The Diplom curriculum's structure was inseparable; the Vordiplom was not a qualification for working, and students could not go directly to the main study period without having passed the Vordiplom. The curriculum of the Diplom study at a university of applied science (Fachhochschule - which offers the Diplom FH degree) on the other hand, was more application-oriented.

With the new higher education system (bachelor-masters), students have a choice whether to continue directly to pursue a master degree; or go for a job after completing their bachelor degree. Students may also pursue their master degree after having worked for some time. Students are not obligated to continue their studies directly after finishing their bachelor study. In this case, bachelor and masters are different levels of degrees.

\section{Internationalization of HEI}

Historically, the internationalization of higher education dated back to the middle ages, when people did religious pilgrimages. The pilgrims did not visit Christ's or a saint's tomb, but a university city where they hoped to find learning environment, friends, and leisure atmosphere. In the twelfth and thirteenth century, when there were not many universities and they were not widely distributed over Europe, the 'happy few' who aspired to higher education had to leave home and travelled a long distance to the 'studium' of their (rather limited) choices (de Ridder-Symoens in de Wit, 2002, p. 5).

Later on, different terms to describe the internationalization of higher education were developed, for instance: international education, international studies, internationalism, transnational education, and globalization of higher education. These terms depend on which approach of internationalization of higher education is being focused.

Kazuhiro Ebuchi (in de Wit, 2002, p. 113) defines the internationalization process of higher education as a process by which the teaching, research, and service functions of a higher education system become internationally and crossculturally compatible. Harari explains that the internationalization of higher education should involve: international content of the curriculum, international movement of scholars and students concerned with training and research, and the arrangements that engage a system of 
education co-operation programs beyond its national boundaries (p. 107). While Jane Knight emphasizes intercultural aspect on her definition that internationalization of higher education is the process of integrating an international/intercultural dimension into the teaching, research and service functions of the institution ( $p$. 113).

Among the numerous terms and definitions of the internationalization of higher education, de Wit (2002) highlights four approaches: activity, competency, rationale, and process.

- Activity approach

This approach emphasizes exclusively on the content of the institution's activities, such as: development and innovation of scholars, students, faculty exchange, area studies, technical assistance, intercultural training, international students, and joint research studies; without including any organizational issue needed to initiate, develop, and sustain the activities. The internationalization of curriculum is the most crucial activity in this approach.

- Rationale approach

This approach emphasizes on the purposes or intended outcome of the internationalization process. Terms frequently used in this approach are: peace education, education for international understanding, development education, and technical assistance. Knight called this approach the ethos approach.

- Competency approach

This approach concerns itself with the internationalization in terms of developing new skills, attitude, and knowledge in students, faculty, and staff. The focus is clearly on the human dimension, not on academic activities or organization issues. There are many terms of competency in this approach: learning and career competencies; global, transnational, and international competencies.

- Process approach

This approach frames internationalization as a process that integrates an international dimension or perspective in the major functions of the institution. The various academic activities, organizational policies and procedures, and strategies, are part of this process. Studies in this area include comparative studies on internationalization strategies of higher education, on national policies, on the link between globalization and internationalization, and on quality assurance and internationalization.

On the other hand, in a research, which discussed about "How International Communication Study in Germany, Austria, and Switzerland" - by questioning 49 Journalism, Communication and Media Studies Institutes in Germany, Austria, and Switzerland in January 2005, was revealed that internationalization had some variables (Rischke, 2005):

1. Internationalization in teaching; represented by providing bachelor and masters programs, which are international compatible degrees. The other things were "Unitizing of the Curricula" (Modularisierung der Curricula); using English as the academic language; using European Credits Transfer System (ECTS) as credit point system; and providing amount of subjects/courses offered in 
foreign language every semester.

2. International cooperation; represented by doing research cooperation with other higher education institution from other countries.

3. International mobility; represented by the mobility of students and lecturers in international range, for example scientist exchange program, international internship, international guest lecturer.

4. International association and publication; represented by becoming member of International Communication Association (ICA), International Association for Media and Communication Research (IAMCR). The teachers are supposed to publish articles for international and well-known journals, newspapers, books, or magazines.

5. International infrastructure; represented by providing language course centre in the HEI, so there were possibilities for the students and teachers to learn other languages. Another was by providing institute information (e.g. website, brochure, and poster) in other languages, so that it opens possibility for scientists from overseas to get acquainted with the institution.

\section{Curricula}

According to de Wit (2002), the internationalization of a curriculum is one of the crucial activities in the internationalization of a higher education system. The word curriculum derives from the Latin word 'currere', which refers to 'course' or 'track' to be followed. In the context of higher education it refers to the 'plan for learning' (Akker, 2003).
The curriculum can be observed from different levels of perspective:

- system/society/nation/state (or macro) level

- school/institution (or meso) level

- classroom (or micro) level

- individual/personal (or nano) level.

Designing a curriculum is a very complex endeavour; it should involve all stakeholders of the education system because the output of a curriculum will influence economic, social, and political systems in general. In the case of higher education curriculum design, it should engage academics, students, users (industries), experts in related fields, and the government. Designing a curriculum also needs much time for planning, implementing, and evaluating whether it is suitable for the social system.

This research studied the curriculum at the meso level, which focuses on the institute, or department level, and on the intended level (ideal and formal/ written). Furthermore, Akker elaborates curriculum components that addressed on ten specific questions regarding on the planning of student education. 
Table 1. Curriculum Components

\begin{tabular}{|l|l|}
\hline Rationale & Why are they learning? \\
\hline Aims \& Objectives & Toward which goals are they learning? \\
\hline Content & What are they learning? \\
\hline Learning activities & How are they learning? \\
\hline Teacher role & How is the teacher facilitating learning? \\
\hline Materials \& Resources & With what are they learning? \\
\hline Grouping & With whom are they learning? \\
\hline Location & Where are they learning? \\
\hline Time & When are they learning? \\
\hline Assessment & How far has learning progressed? \\
\hline
\end{tabular}

(Akker, 2003)

In the meso level, the observation of curriculum components is focused on the first three items: rationale, aims and objective, and content; whereas the others are more applicable in the micro level.

\section{World Wide Website for HEI}

This research analyzed the media and communication study's curricula documents, which are performed in the HEI's websites. For HEI the WWW is very useful for research, teaching, and communication amongst staff and students; additionally it is also a very useful tool to advertise the institution. Through website, HEI can reach its internal and external public altogether. For internal public, the website has a function to serve a good interaction and a good communication environment among staff and students: e.g. to ease the access to institution data base, to simplify reaching the contact address/telephone/facsimile, to enable to get downloadable course material, discussion forum, information about clubs and their activities. On the other hand, for public the website should be attractive and provide good reasons for them for "doing business" with the institution: e.g. course/prospective information, local information, frequently ask information, mission statement, travel and accommodation information. The primary function of a website is to provide information, and also to provide links to where the information may potentially be found. (Middleton, McConnell and Davidson; 1999).

According to Middleton, McConnell, and Davidson, there are three kinds of information, which can be provided by HEI in its website:

1. Promotional information; advertising services, assets and achievements to potential customers, collaborators and recruits (recruits for both staff and students)

2. Value-added information; providing useful services to people, encouraging their return and enhancing the reputation's institution as an innovative information provider.

3. Benefits for staff and students; information, services, and resources that will enable an institution to reach its strategic aims more easily, facilitate internal and external communication and enhance education.

Commonly, the better an institution presents itself in any medium, the more successful it will be at attracting students, academics, business, or whoever wishes to engage. 
Media and Communication Studies in German's HEI

Media and communication study has an interdisciplinary character; this study develops in diverse sub-disciplines, depending on which faculty it is merged in, for example: media economics, media psychology, media sociology, media pedagogy, media politics, media aesthetic, media law, media management, media history, media technology, design/ visual communication, journalism, online journalism, political communication, film study, etc. Nevertheless, this tremendous branching also makes this study difficult to be mapped and to be identified in its exact quantity.

Media and communication study is one of a highly demanded subject study in German's HEI. The applicants of this subject increase every year. There were 23,276 applicants in 2003, and in 2007 the number had increased to approximately 34,474 applicants (Rössler 2007, p. 1213). It is not surprising that media and communication study in every HEI commonly has Numerus Clausus (nationwide quota); they require the applicants to have a very good or good $(1.3-2.3)$ Abitur (high school final exams) average grade; even in the journalism department of some universities of applied sciences requires the applicants to prove their talent for journalism by doing a trial report (Walser, 2008).

According to $\underline{w w w}$. $\underline{\text { medienstudienfuehrer.de, }}$, there are 280 media and communication study programs in Germany, either as major or as minor subjects in bachelor or masters programs. Half of them $(50.7 \%)$ are offered by university of applied sciences (Fachhochschule); the rest is provided by university (38.2\%), private higher education institution (5.0\%), Art and Music University (4.6\%), and university of cooperative education (1.1\%). The most bachelor programs are provided by Fachhochschule (61\%); those are not astonishing because the curricula of bachelor program have more practical orientation. Conversely, the most of masters programs $(64.3 \%)$ are provided by the university, which has more theoretical and conceptual orientation.

\section{Table 2. Bachelor and Masters Programs of Media and Communication Study}

\begin{tabular}{|c|c|c|c|c|c|c|}
\hline \multirow[t]{2}{*}{ Higher Education Institution } & \multicolumn{2}{|c|}{ Bachelor Degree } & \multicolumn{2}{|c|}{ Masters Degree } & \multicolumn{2}{|c|}{$\begin{array}{l}\text { Bachelor \& } \\
\text { Masters }\end{array}$} \\
\hline & Number & $\%$ & Number & $\%$ & Number & $\%$ \\
\hline University (Universität) & 48 & 25.7 & 59 & 64.3 & 107 & 38.2 \\
\hline $\begin{array}{l}\text { University of Applied Science } \\
\text { (Fachhochschule) }\end{array}$ & 114 & 61.0 & 28 & 30.4 & 142 & 50.7 \\
\hline Art and Music's University & 8 & 4.2 & 5 & 5.2 & 13 & 4.6 \\
\hline $\begin{array}{l}\text { University of Cooperative } \\
\text { Education (Berufakademie) }\end{array}$ & 3 & 1.6 & 0 & 0.0 & 3 & 1.1 \\
\hline Private HEI (Private Ausbildung) & 14 & 7.5 & 0 & 0.0 & 14 & 5.0 \\
\hline Other & 0 & 0.0 & 1 & 1.1 & 1 & 0.4 \\
\hline Total & 187 & 100.0 & 93 & 100.0 & 280 & 100.0 \\
\hline
\end{tabular}

(medienfuehrer, 2008) 
The subject orientation of this study is very heterogeneous. The popular subject orientations are in Publizistik/ Communication Science (18.6\%); and then it is followed by Multimedia/Informatics
(13.9\%), Media Economics (12.9\%), Media Science $(11.4 \%)$; and reaching the smallest number are Pedagogy Media and Public Relations (7\%).

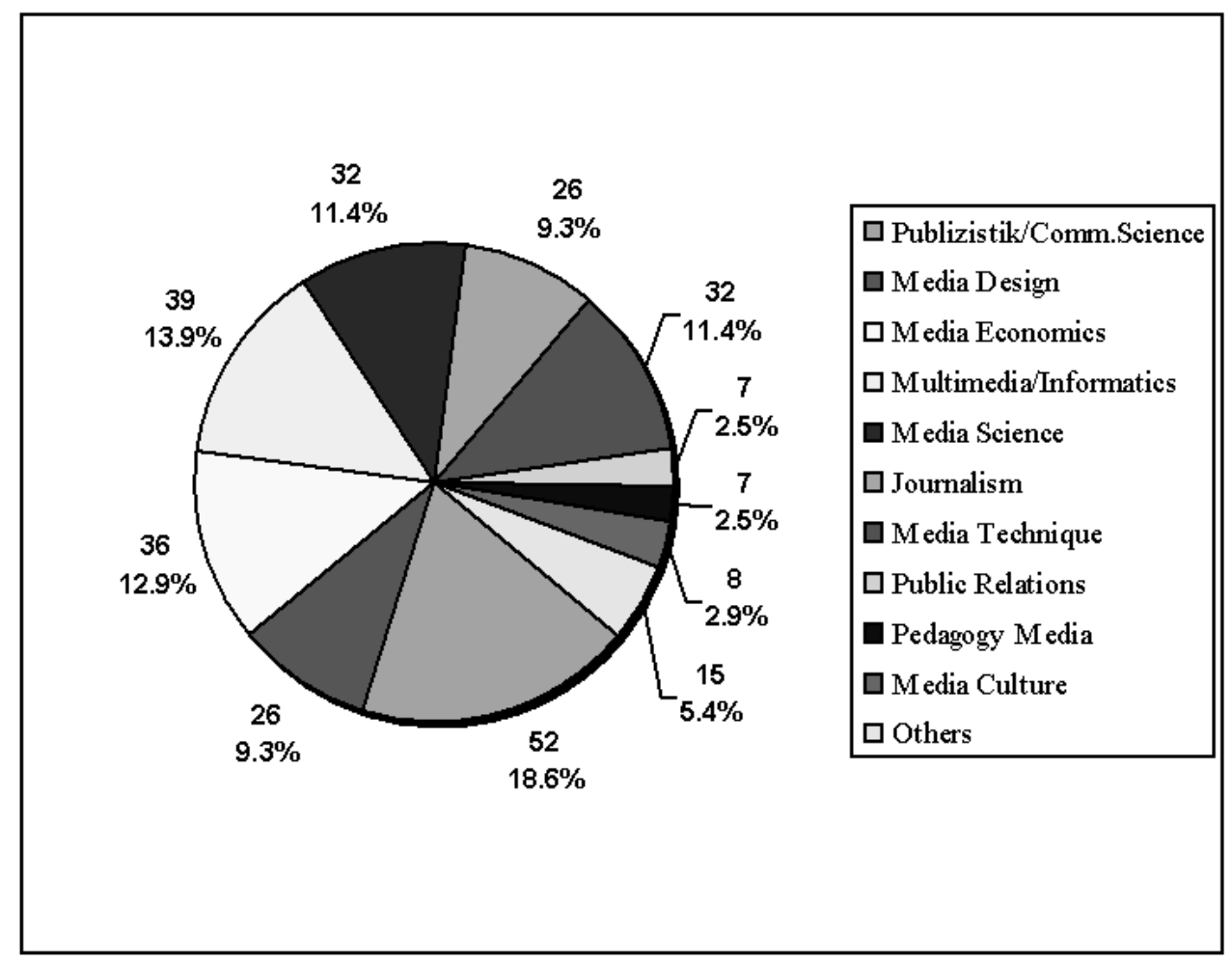

Figure 1. Subject Orientation of Media and Communication Study $(\mathrm{N}=\mathbf{2 8 0})$ (medienfuehrer, 2008)

Student booming in media and communication study is parallel to the job market of this study. According to Rang, Rühl, and Heinz (2007), from thelast twelve years there was an increase of journalist profession from 54,000 to 61,000; while journalist vacancy increased also about $13 \%$ (1,610 vacancies) compared to 2006 $(1,423)$ (p. 4). The media graphic designer vacancy decreased a little bit about 3.4\% $(3,774)$ from $2006(3,919)$ (p. 23-24). Even the profession in the Publizistik sector (e.g. Editorial Staff, Journalist in general, Copywriter, Lecturer, Public Relations, Radio-/Television News Anchor) also increased about $1.6 \% \quad(24,511)$ from $2006(24,119)$ (p. 16). The high demand for media and communication study graduates is indicated by the increase of online media investment in Germany. Multimedia-Journalism develops in line with the sophistication of Information and Communication Technology (ICT). It makes the media and communication study graduates have a chance as good as their friends from engineering faculty.

\section{Methodology}

This research used the content analysis method to analyze data and to 
answer the research questions. According to Waples and Berelson (in Berelson 1971, p. 14), a content analyses attempts to define more casual descriptions of the procedure, and to analyze objectively the nature and strength of the stimuli applied to the reader or listener. In conducting the content analysis, the researcher searched for common themes that emerged once the study began. In this research, the units of analysis are the following:

1. Word-level/diction; including phrases, which have meaning or represent "internationalization" for example: Bologna Process, intercultural, multicultural, cross-cultural, global, transnational, bilingual.

2. Paragraph and sentence-level; simple sentences, which describe "internationalization".

3. Item; website, study regulation (Studienordung), (electronic) brochure, and courses description.

This research used a qualitative approach, which analyzed written documents of curricula and transcription of interview. Content analysis on written documents is made use to find the fundamental data of curricula, which are usually done by HEIs to legalize their regulations. These documents especially could be found at the masters program's websites. It is without a doubt that we would always try to look for curriculum information before we study something at a HEI. A website is a "one stop information tool" for HEIs now. Furthermore it is an interactive media for HEIs and their audience that can be easily accessed by a worldwide audience. The data analysed were taken on 1-31 July 2008 from each of the institution's websites.

The researcher also conducted interviews with some heads and representations of master of media and communication programs to verify the data that was found in written document content analysis. The interviewees were the representatives of HEIs, which were supposed to know the internationalization process of the master programs curricula.

The samples of this study were HEIs, which were chosen purposively by the guidance of the CHE-University Ranking of Media- and Communication Science, Journalism (Walser, 2008). Due to the limitation of time and finances, this research took the following samples:

1. The Department of Communication Studies (Kommunikationswissenschaft) at University of Erfurt; this institution was chosen because it was ranked on the top in all categories of CHEUniversity Ranking of Media- and Communication Science, Journalism: Research Reputation, Study Organization, Practice Support, Counselling, and Overall Study Situation.

2. The Institute of Social Sciences (Institut für Sozialwissenschaftliches - Masters of Political Communication) - Heinrich Heine University of Düsseldorf; this institution was chosen because it was ranked on the top in every category, except the Research Reputation, in which was ranked at midrange.

3. The Institute of Journalistic and Communication Research (Institut für Journalistik und Kommunikationsforschung) - Hochschule für Musik und Theater (HMT) Hannover; this institution was chosen because it was ranked on the top of every category, except the Research Reputation, in which was ranked at midrange. 
4. The Institute for Media and Communication Sciences (Institut für Media und Kommunikationswissenschaft) - Ilmenau University of Technology; this institution was chosen because it was ranked on the top of every category, except the Research Reputation, in which was ranked at midrange.

\section{Findings}

The four of institute/department of media and communication studies that were chosen as sample in this research have implemented the principle of the "comparable and compatible qualification" of the Bologna Process in their curricula system; although the Department of Communication Science - University of Erfurt and Institute of Journalism and Communication Research (IJK), HMT - Hannover were still not really sure whether the Bologna Process was equal to internationalization; while Institute of Social Science (ISS) University of Düsseldorf and Institute of Media and Communication Science (IfMK )- TU Ilmenau explicitly agreed that both were equal but actually Bologna Process would afford more than just internationalization.

With the different intensity, all of them had tried to actualize the variables of internationalization of HEI, which consisted of internationalization in teaching, mobility of students and lecturers, cooperation, association and publication, and infrastructures. They considered that international student's mobility was the most important thing to be prioritized, because they expected there were initial contacts from them with foreign HEIs and henceforth they could cooperate more intensively in researches or lecture exchange programs. However, typically only bachelor students who could really make use of these abroad exchange semester opportunities; with regards that the masters program curriculum, which usually has duration of three or four semesters, was too short and too rigid to utilize these opportunities.

The uniqueness of the Department of Communication Science - University Erfurt and IJK - Hannover were not only a department that their students were interested to have a formal cooperation with them. They tried to open the opportunities as wide as possible to support the student's mobility; they just suggested them to see which courses that were suitable and could be converted to their institute/department.

The other types of international cooperation in research and guest lectures were not easy to trace except that one could be found in the websites, because most of them were hold as personal cooperation among professors in those departments/ institutes. The individual professors had opportunity to develop international cooperation without any formal support among university's administration. These conditions prevailed also on the association and publication that each institution had difficulties to trace exactly with which association and what kind of publication their lecturers had made. Due to the limitation of time the researcher could not achieve those data.

In part of the infrastructure, IfMK and IJK regarded that website was the most useful communication tool, because they also tried to attract overseas students to join their academic life. In the supporting units, on the other hand, most institutions (except IJK - Hannover) had university language centre as division, which gave them possibility to provide language 
training either for their own students and lecturers or for the guest students or lecturers. IfMK and ISS implicitly provided "international division" in their website institute to take care of student's mobility (outgoing or incoming students), while the Department of Communication Science - University of Erfurt and IJK did not implicitly provided the same division but they had personnel who took in charge in this particular thing.

Among those four institutes/ departments only the Department of Communication Science, University of Erfurt that did not have any experience in transformation process from Diplom/ Magister system into bachelor-masters system, because they established their institute with bachelor-masters system totally new in 1999. IfMK explained that they did not just split up their Diplom Angewandte Mediewissenschaft program into bachelor and masters program, but they really prepared and planned the new masters program (in Media and Communication Research) to be international one, whereas the bachelor program still used "Angewandte Medienwissenschaft" attribute. The representatives of ISS and IJK were not really certain about the transformation process of curriculum of their each institution because both of them were relatively new in their institution.

Generally, there were anxieties on those institution's representatives that in the future many students would just "feel enough to have bachelor degree" and they would not come back to HEI to pursue higher degree (masters or doctor), either because they would have felt "established" to work in industries or they would not own an enthusiasm to have further study because they would not bother engaged themselves in the complexity of sciences. But in the positive side they were sure that the new curriculum structure was clearer and more transparent than the previous one, so the lecturers and students could make a plan much better on their academic's activities. By large they had almost the same opinion that their new curriculum system should be frequently evaluated, whether they were suitable or not with the science development and the professional demand.

\section{Conclusion and Recommendation}

Overall, this research found out that internationalization of higher education system through the Bologna Process in those four HEIs was still an ongoing process until the targeted time by 2010. Actually with or without the Bologna Process, the HEI's had done international actions in many activities, such as international cooperation in research and teaching; publishing articles in international journals, books, and conferences; engaging in international communication and media association. Currently, the focus on the Bologna Process is to emphasize their policies and activities in European scope, such as international students exchange (incoming and outgoing) and internships; implementing bachelor and masters structure in their programs; providing more courses in English; and strengthening international content in their courses.

The Bologna Process was of course not without any controversy for them; they were very curious about the real result of the Bologna Process in short time at least after 2010. The main policies in the Bologna Process that become a "source of anxiousness" were the implementation of bachelor and masters system in their 
curricula; they were still in "trial and error" in modifying the content and the load of work distribution between bachelor and masters programs. Implementation of bachelor and masters system caused a reduction of study period and then was followed by the reduction of content and the load of work of the students who pursued bachelor and masters degree. The period before the Bologna Process, the curricula of media and communication studies in the university type HEI in Germany (Universität and Hochschule) tend to be empirical and theoretical studies because they aimed to prepare the young scholars; whereas currently they must also prepare their students to get involved in industries which were previously prepared by university of applied science (Fachhochschule).

This research concluded that among the anxiety of the HEI there were also "source of refreshment" that in the new curricula system the structure was clearer; the reduction of the study period has minimized the number of the dropout students, thatstudentshadchoiceswhether they would go to work in industries or directly to pursue their masters degree; and of course, the curriculum system was more internationally recognised, more attractive to international students, and international scientific climate was formed.

Besides, a reformation of education system is always become a big event wherever it occurs because education is a foundation of a nation; changes in the education system would give an impact on the nation in wide scale. Moreover, when the changes implemented in higher education level, it would influence directly to the demand of work forces and political and economic stability.
As an initial research, this study could not depict completely internationalization process that occurred in every HEI in Germany, due to the time and financial restriction. The limitation of researcher's comprehension on the curriculum's theoretical conception resulted in inadequate observation and data analysis. Examined curriculum through content analysis on written documents (website, electronic brochure, study regulation, and course description) without observing directly to the application in the class was very difficult to get comprehensive process, because the researcher observed only on written document; a written document of curriculum usually emphasizes something that is very ideal. Preferably, this research also involved the representative from the Bologna Process authority, students, and experts in higher education system so we could get a comprehensive implementation and evaluation of the Bologna Process.

Furthermore, this research only observed one type program: masters program, it did not involve the bachelor program; whereas the real condition in the field is that the masters program always has a connection to its bachelor program, whatever the type it is. Because of that this study could not examine clearly how the correlation of the curriculum of masters program to the bachelor program's curriculum. On account of time and financial restriction, methodologically, this research only took the four top ranking media and communication departments/institutes in Germany, so it could not illustrate the real implementation and impacts of internationalization in the national scope.

In the future, the researcher expects that there would be more comprehensive researchers to examine 
the internationalization in media and communication's curricula. Hopefully, they would examine all the media and communication programs in Germany and the lecturers, students, the representatives of accreditation institution, German Federal Ministry of Education and Research, experts in higher education system would also get involved; so it would attain more inclusive result that could become a data base for media and communication studies in Germany. The data could be used as a base of comparative research on the particular topic in other countries.

\section{Acknowledgment}

I would like to thank to PD Dr. phil. habil. Frauke Zeller (IfMK at TU Ilmenau), who guides and supports this research; Deutscher Akademischer Austausch Dienst (DAAD) for all resources for me to do this research.

\section{Bibliographies}

Akker, J.J.H. van den. (2003). Curriculum perspectives: an introduction. In J. van den Akker, W. Kuiper \& U. Hameyer (Eds.). Curriculum landscape and trends. Dordrecht: Kluwer Academic Publishers.

Berelson, Bernard (1971). Content Analysis in Communication Research. New York: Hafner. 13-57.

Bologna Secretariat. (2007). Bologna Process and European Higher Education Area. Available: http://www.ond. vlaanderen.be/hogeronderwijs/ bologna/. Last accessed 4 April 2008. de Wit, Hans (2002). Internationalization of Higher Education in the United States of America and Europe. Westport: Greenwood. 3-233.

Der Spiegel (18/2008). Die StudentenFabrik. 56-69.
Institut für Journalistik und Kommunikationsforschüng. Available: http://www.ijk.hmthannover.de/. Last accessed 29 November 2008.

Institut für Medien- und Kommunikationswissenschaft. Available: http:// www.tu-ilmenau.de/ifmk/. Last accessed 29 November 2008

Knoke, Mareike . $\quad$ (5 March 2007). GRATULATION MIT GRABREDE: Happy Birthday, Magister!. Available: http:// www.spiegel.de/ unispiegel/ studium/0,1518,468934,00.html. Last accessed 9 April 2008.

Kommunikationwissenschaft, Universität Erfurt. Available: http://www. kommunikationswissenschafterfurt.de/. Last accessed 29 November 2008

Masterstudiengang Politische Kommunikation. Available: http://www.master-politischekommunikation.de/masterpolitische-kommunikation/. Last accessed 29 November 2008.

Reitze, Helmult (Hrg) (2007). Media Perspektiven, Basisdaten. Frankfurt: Media Perspektiven. 4-92.

medienstudienfuehrer. Medienstudienfuehrer. Available: http://www. medienstudienfuehrer.de/home. html. Last accessed 16 July 2008.

Middleton, Iain., McConnel, Mike., Davidson, Grant. (1999). Presenting a Model for to the Structure and Content of a University World Wide Website. Journal of Information Science. 25 (3), 219-227.

Rang, Marion., Rühl, Oliver., Heinz, Mark. (2007). Arbeitsmarkt Kompakt 2007: Medien-und Kreativberufe. Bonn: Bundesagentur für Arbeit. 1-36.

Rischke, Melanie. (2005). Internationalisierung: Es hält sich in Grenzen. AVISO. 40 (1), 12-13 
Rössler, Patrick. (2002). Konsekutive Studienmodelle auf dem Vormarch. AVISO. 31 (1), 22-23.

----------- (2004). Trotz Überlast: Nachfrage Ungebrochen. AVISO. 36 (1), 19-21.

(2007). Inszwieschen Standard. AVISO. 45 (1), 12-13.

Schulz, Wolfgang. Scheuer, Alexander (2005). Media System of Germany. Hamburg: Hans Bredow Institute and Institute of European Media Law. 1-20.

The Langenscheidt Dictionary e-Grosswörterbuch Deutsch als Fremdsprache 4.0

Walser, Joerg. (2008). University Ranking: Media- and Communicational Science, Journalism. Available: http:// ranking.zeit.de/che9/CHE_en?mod ule $=$ WasIst\&do $=$ show\&esb $=41$. Last accessed 15 May 2008. 